United States and Japan sign agreement on nuclear reprocessing

Tokyo

Nuclear power entered a new era in Japan last week with the signing of an agreement with the United States. The new bilateral pact gives Japan greater freedom to reprocess spent nuclear fuel, opens the way to commercial reprocessing in the mid- $1990 \mathrm{~s}$, and allows the export of Japanese nuclear power technology to the United States for non-military purposes. But the agreement also calls for the shipment of vast quantities of plutonium to Japan by air after reprocessing in Europe. And there is strong opposition to the plan in Alaska, which lies under the most likely flight path.

Despite the accident at Chernobyl, the Japanese government is eager to expand its nuclear power facilities. The Atomic Energy Commission forecast earlier this year that by the year 2000 nuclear power will provide 40 per cent of the nation's energy, compared with the present level of 27 per cent, and 7 million million yen ( $\$ 50,000$ million) will be invested in the nuclear power industry over the next 13 years.

Japan already has more than 30 nuclear power stations in operation, which produce around 700 tons of spent fuel a year, but only about 10 per cent of this can be handled by Japan's small reprocessing plant in Tokaimura, Ibaraki Prefecture; the bulk of the nation's spent fuel is reprocessed in Britain and France.

Under terms of an agreement signed in

\title{
Axe falls on Irish agricultural researchers
}

DESPITE recent declarations of the economic importance of increased research and development, the Irish government is to reduce its support of agricultural and food research by almost half next year. An Foras Taluntais (AFT), the agriculture and food research institute, is to be merged with ACOT, the agricultural advisory and training service. The state grant for the new body will be IR $£ 20$ million (about $£ 22$ million), a 43 per cent reduction on the joint total of IR $£ 35$ million this year. Voluntary early retirement and redeployment of staff within the public sector is expected to achieve a staff reduction from 2,200 to $1,200$.

Although rumours of a merger have been circulating for some months, the severity of the financial cuts has taken everyone by surprise, particuarly as the government had been emphasizing increased research and technological development as a key factor in its "programme for national recovery", announced last month. The cuts are also surprising given the importance of agriculture to the Irish economy.

Almost 12 per cent of Irish gross national product (GNP) is attributable to the agricultural sector, compared with 2-4 per cent of GNP for most other members of the European Economic Community (EEC). However, proportionally less state money is invested in agricultural research in Ireland than is the case in most other developed countries. In 1985 the Irish government spent IR $£ 178$ per agricultural worker; on a comparable scale, Belgium and The Netherlands spent twice as much, whereas Britain spent three times as much.

AFT's state grant this year is IR $£ 17$ million, 67 per cent of its total income, the balance coming from farm operations and research contracts (with more than IR£1 million from EEC projects). Even before the latest cuts take effect, the state grant has declined in real terms by 25 per cent since 1981. Over the past five years, nine field stations have been closed and staff members reduced by 200 to the present level of 1,134 .

The Department of Agriculture, which administers the AFT and ACOT grants, says the cuts are necessary "to reduce public expenditure". Within the department, however, AFT and ACOT seem to have been singled out for particularly drastic reductions - the department's allocation for its own administrative budget next year is only 2 per cent down on this year.

The severity of the cuts will almost certainly mean the closure of whole areas of research. So far the government has not indicated its priorities, and it now seems that the newly merged body will decide at a local level how best to implement the reductions.

This apparent lack of any underlying strategy by the government has caused considerable concern to AFT's 240 research staff who now fear that the government is forgetting the primary role played by research and the logistics involved in running a comprehensive research programme.

The cuts to AFT and ACOT are only the latest in a series of government measures to reduce public expenditure. The Institute for Industrial Research and Standards and the National Board for Science and Technology, which together employs 650 staff, are to be merged with a loss of 100 jobs, and An Foras Forbartha, which employs 200 people and is responsible for physical and environmental planning, is to be abolished.
1968, Japan must obtain prior approval from the United States before shipment or reprocessing of any fuel of US origin (a condition which applies to most of Japan's nuclear fuel).

The new pact, signed in Tokyo last week by Japan's foreign minister and US ambassador Mike Mansfield, grants Japan blanket approval for the reprocessing and transport of recycled fuel for the next 30 years, a move that should allow the smooth operation of a commercial reprocessing plant due to open in Aomori Prefecture in 1995 (see Nature 322, 399; 1986).

During the late 1970s the Carter administration in the United States, which advocated a strong policy of nuclear nonproliferation, caused considerable delays to the opening of the Tokaimura plant, and it was largely to break free of such restrictions that Japan began negotiating the present pact with the Reagan administration in 1982

But even after the plant in Aomori opens, Japan will continue to send vast amounts of spent fuel to France and Britain for reprocessing. The new accord requires that the plutonium produced in Europe should be shipped back to Japan by air. With an expected $40-50$ tons of plutonium to be transported in the 1990s, this would require several flights a year. The expected route is over the North Pole and Canada, with a refuelling stop in Anchorage.

Alaskan governor Steven Cowpar has considerable reservations about the plan and has asked Congress to seek necessary environmental safeguards before approving the new pact. In particular, he demands assurances that the plutonium will be shipped in crash-proof containers. But, as pointed out by the US Nuclear Control Institute in a report last year, suitable casks have yet to be developed. And there are fears that in the event of a plane crash the highly toxic plutonium could be sprayed across the countryside.

There are also concerns that Japan may not take adequate measures to prevent hijacks. A few years ago the United States initially vetoed a plan by Japan to transport a large plutonium load from France by ship because of inadequate preparations for escort and surveillance. But critics say that with the signing of the pact such veto rights are lost.

So what does the United States gain out of this agreement? Japan has made considerable advances in the development of technology for the nuclear power industry, for example, advanced technology and robots are being used to dismantle Japan's first experimental reactor (see Nature 325, 100; 1987). And under the accord, such technology can be transfered or exported to the United States, provided it is used for non-military purposes.

David Swinbanks 